\title{
*
}

\section{Gregory of Nyssa:}

\section{The Minor Treatises}

\section{on Trinitarian Theology}

\section{and Apollinarism}

Proceedings of the 11th International

Colloquium on Gregory of Nyssa

(Tübingen, 17-20 September 2008)

\section{$*$}

Edited by

VOLKER HENNING DRECOLL

AND MARGITTA BERGHAUS 
Gregory of Nyssa: The Minor Treatises on Trinitarian Theology and Apollinarism 


\title{
Supplements
}

to

\section{Vigiliae Christianae}

\author{
Texts and Studies of \\ Early Christian Life and Language
}

\author{
Editors \\ J. den Boeft - B.D. Ehrman - J. van Oort - \\ D.T. Runia - C. Scholten - J.C.M. van Winden
}

VOLUME 106

The titles published in this series are listed at brill.nl/vcs 


\title{
Gregory of Nyssa: The Minor Treatises on Trinitarian Theology and Apollinarism
}

\author{
Proceedings of the 11th International \\ Colloquium on Gregory of Nyssa \\ (Tübingen, 17-20 September 2008)
}

\section{Edited by}

Volker Henning Drecoll and Margitta Berghaus

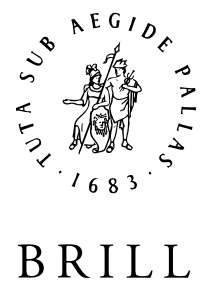


This book is printed on acid-free paper.

Library of Congress Cataloging-in-Publication Data

International Colloquium on Gregory of Nyssa (11th : 2008 Tubingen, Germany)

Gregory of Nyssa : the minor treatises on trinitarian theology and Apollinarism : proceedings of the 11th International Colloquium on Gregory of Nyssa (Tubingen, 17-20 September 2008) / edited by Volker Henning Drecoll and Margitta Berghaus.

p. cm. - (Supplements to Vigiliae Christianae. Texts and studies of early Christian life and language ; v. 106)

Includes bibliographical references and index.

ISBN 978-90-04-19393-2 (hardback : alk. paper) 1. Trinity-History of doctrines-Early church, ca. 30-600. 2. Gregory, of Nyssa, Saint, ca. 335-ca. 394-Congresses.

3. Church history-Primitive and early church, ca. 30-600-Congresses. 4. Apollinaris, Bishop of Laodicea, d. ca. 390-Congresses. I. Drecoll, Volker Henning. II. Berghaus, Margitta. III. Title.

BT109.I56 2008

231'.044-dc22

2010050617

ISSN 0920-623x

ISBN 9789004193932

Copyright 2011 by Koninklijke Brill NV, Leiden, The Netherlands.

Koninklijke Brill NV incorporates the imprints Brill, Global Oriental, Hotei Publishing,

IDC Publishers, Martinus Nijhoff Publishers and VSP.

All rights reserved. No part of this publication may be reproduced, translated, stored in a retrieval system, or transmitted in any form or by any means, electronic, mechanical, photocopying, recording or otherwise, without prior written permission from the publisher.

Authorization to photocopy items for internal or personal use is granted by Koninklijke Brill NV provided that the appropriate fees are paid directly to The Copyright Clearance Center, 222 Rosewood Drive, Suite 910, Danvers, MA 01923, USA.

Fees are subject to change. 


\title{
CONTENTS
}

Introduction .......................................................................... ix

List of Participants / Teilnehmerliste …........................................ xxiii

List of Abbreviations ............................................................... Xxv

\author{
PART ONE \\ TRANSLATIONS \\ Volker Henning Drecoll
}

I.1 Ad Eustathium, De sancta trinitate

(GNO III/1, 3-16 Müller) ……………………………….... 3

I.2 Ad Graecos, Ex communibus notionibus

(GNO III/1, 19-33 Müller) ................................................... 13

I.3 Ad Ablabium, Quod non sint tres dii

(GNO III/1, 37-57 Müller) .................................................. 25

I.4 Ad Simplicium, De fide (GNO III/1, 61-67 Müller) ........... 39

I.5 Adversus Macedonianos, De spiritu sancto

(GNO III/1, 89-115 Müller) ................................................... 45

I.6 De deitate filii et spiritus sancti et In Abraham

(GNO X/2, 117-144 Rhein)

DETAILED ANALYSIS OF THE MINOR TREATISES

ON TRINITARIAN THEOLOGY

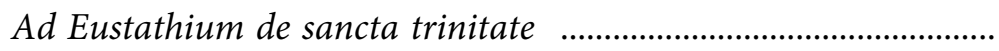

AndRew RadDe-Gallwitz

Logic and the Trinity: Introducing Text and Context of Gregory of Nyssa's Ad Graecos JoHAN LEEMANS

Ad Ablabium, Quod non sint tres dei 
Gregory on the Christocentric Simplicity of the Trinitarian Worship: The Contribution of Gregory of Nyssa's Short Treatise Ad Simplicium tribunum ARI OJELL

The Fire, the Kingdom and the Glory: The Creator Spirit and the Intra-Trinitarian Processions in the Adversus Macedonianos of Gregory of Nyssa Giulio Maspero

De deitate filii et spiritus sancto et In Abraham MatThieu Cassin

PART THREE

\section{SUPPORTING STUDIES}

\section{III.1 Theological and Philosophical Themes}

God is not the name of God. Some Remarks on Language and Philosophy in Gregory's Opera dogmatica minora Marcello La Matina

Human Communion and Difference in Gregory of Nyssa: From Trinitarian Theology to the Philosophy of Human Person and Free Decision

Francisco Bastitta Harriet

Gregory's Metaphysical Investments JosePh S. O'LeARY

St Gregory's argument concerning the lack of $\delta$ ió $\sigma \tau \eta \mu \alpha$ in the divine activities from Ad Ablabium Vladimir CvetKovic

Die Vermittlung des Sohnes beim ewigen Ausgang des Heiligen Geistes aus dem Vater nach Gregor von Nyssas Ad Ablabium (GNO III/1, 55,21-56,10 Müller) Georgios D. Panagopoulos 
Power, Motion and Time in Gregory of Nyssa's

Contra fatum

George Arabatzis

\section{III.2 In illud: Tunc et ipse filius}

In illud: Tunc et ipse filius

MORWENna LudLow

Interpretation and Argumentation in In illud:

Tunc et ipse filius

Judit D. Tóth

Gregory of Nyssa's Trinitarian Theology in In Illud:

Tunc et ipse filius. His Polemic against "Arian"

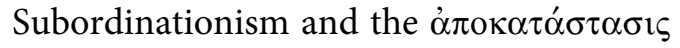

ILARIA RAMELLI

\section{III.3 The Debate with Apollinaris}

Anti-arianische Argumente gegen Apollinarios. Gregor von

Nyssa in der Auseinandersetzung mit Apollinarios in

Antirrheticus adversus Apolinarium

Silke-Petra Bergjan

La polemica apollinarista alla fine del IV secolo: La lettera di Gregorio di Nissa a Teofilo di Alessandria Alessandro Capone

Der eine Christus vor, in und nach dem Fleisch-Einige Überlegungen zu Gregor von Nyssas Ad Theophilum adversus Apollinaristas

BenJAMIN GLeEde

Comment décrire l'humanité du Christ sans introduire une quaternité en Dieu? La controverse de Grégoire de Nysse contre Apolinaire de Laodicée 
Gregory of Nyssa's refutation of the pre-ensoulment of God the Word in his Antirrheticus adversus Apolinarium Georgios LeKKas

\section{III.4 Reception}

In Search of the Latin Translator of Gregory of Nyssa's

Letter to the Monk Philip

AnNa M. Silvas

Old Georgian Translations of Gregory of Nyssa’s Works

The Slav Reception of Gregory of Nyssa's Works:

An Overview of Early Slavonic Translations

Lara Sels

Die Berufung der byzantinischen Filioquisten des 13.

Jahrhunderts auf Gregor von Nyssa zur Begründung des filioque. Analyse eines Zitats aus Ad Ablabium (

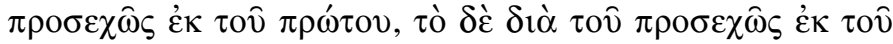
$\pi \rho \omega ́ \tau о v)$

Theodoros Alexopoulos

The Trinity and Textuality or Der Ursprung des Textwerkes ... Scot Douglass

Bibliography

Indices

I. Index Locorum

II. Index Nominum 


\title{
ST GREGORY'S ARGUMENT CONCERNING THE LACK OF $\triangle I A \Sigma T H M A ~ I N ~ T H E ~ D I V I N E$ ACTIVITIES FROM AD ABLABIUM
}

\author{
Vladimir Cvetkovic
}

This paper intends to shed new light on Gregory's usage of the dialectal pair $\delta i \alpha ́ \sigma \tau \eta \mu \alpha-\dot{\alpha} \delta \dot{\alpha} \alpha \tau \alpha \tau \tau$, specifically in the Trinitarian context of Ad Ablabium. The bold expression in the title of this paper referring to Gregory's argument concerning the lack of $\delta 1 \alpha$ ó $\sigma \tau \eta \mu \alpha$ in the divine activities from Ad Ablabium requires an explanation. My intention is not to add a new argument to the list of the already existing argumentation, but to demonstrate that Gregory's arguments were developed in the debate with Anomeans over the question whether temporal $\delta$ ió $\sigma \tau \eta \mu \alpha$ exists in divine being or not. By rejecting Anomean claims, Gregory develops a completely new Trinitarian doctrine, based on the "adiastemic" nature of God and on the "hypostatic" distinctions between the divine persons.

\section{Historical development of the term $\delta \mathrm{i} \alpha \tau \tau \eta \alpha$}

The term $\delta i \alpha ́ \sigma \tau \eta \mu \alpha$ had had its historical development before Gregory made of it one of the essential notions of his theology. Gregory might have received the term from a few different sources. One might have been Origen and Methodius of Olympus, who borrowed this term from Philo and the Stoics. Balthasar is the first who in his pioneering work on Gregory from 1942 (Présence et pensée) suggests that the Stoics are the possible source of Gregory's $\delta$ ió $\sigma \tau \eta \mu \alpha .{ }^{1}$ Stoics were among the first philosophers who used the term $\delta$ ió $\sigma \tau \eta \mu \alpha$ in order to define extension in time or time in general, ${ }^{2}$ unsatisfied with both

${ }^{1}$ Hans U. von Balthasar: Presence and Thought: An Essay on the Religious Philosophy of Gregory of Nyssa, translated by Marc Sebanc (San Francisco: Ignatius Press, 1995), 32 , note 46.

${ }^{2}$ Simplicius, In Aristotelis Categorias commentarium (CAG 8, 350,15f. Kalbfleisch). Simplicius also testifies that the first who used the term $\delta$ ió $\sigma \tau \eta \mu \alpha$ to define movement is the Pythagorean Archytas (see Simplicius, In Aristotelis Physicorum libros octo commentari [CAG 9/1, 786,12f. Diels]), although Sambursky finds that Simplicius' 
Plato's definition of time as the moving image of eternity ${ }^{3}$ and Aristotle's definition as number of motion in respect of "before" and "after". Chrysippus maintained that, due to the constant change in the sensible world, Plato's conception of time could not offer a fixed point in time to serve as a reference for events. ${ }^{5}$ In order to express better the nature of time as continuum, Zeno replaced Aristotle's "number"

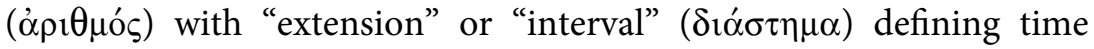
as the extension of movement. ${ }^{6}$ Chrysippus went further than Zeno defining time as the extension of proper movement of cosmos and stating that everything that moves and exists is in time. ${ }^{7}$ By linking closely time and cosmos, Chrysippus connected the "cosmic" cycles with temporal cycles and thus treated the beginning and end of each "cosmic" cycle as fixed point in time. ${ }^{8}$

Balthasar also states that Philo could also be a source of Gregory's $\delta ı \alpha ́ \sigma \tau \eta \mu \alpha$. Philo by following Stoics, especially Chrysippus, ${ }^{9}$ defines

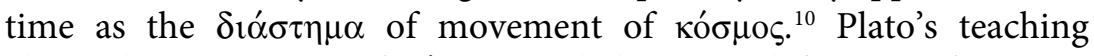
about the generation of кó $\sigma \mu \varsigma_{s}$ and the Stoic definition of time as $\delta$ ió $\sigma \tau \eta \mu \alpha$ between two world fires of cosmic cycles served for Philo as philosophical vindication of Moses' account of creation of the world from Genesis.

quotation is from spurious sources. See Samuel Sambursky: Physics of the Stoics (New York: Macmillan, 1959), 101.

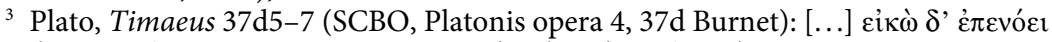

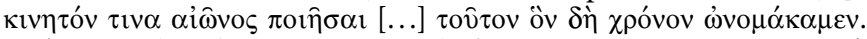

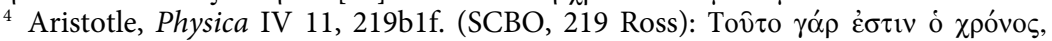

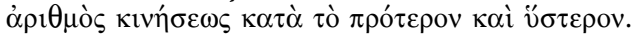

${ }^{5}$ John M. Rist: Stoic Philosophy (Cambridge: Cambridge University Press, 1969), 276.

${ }^{6}$ Simplicius, In Aristotelis Categorias commentarium (CAG 8, 350,15f. Kalbfleisch):

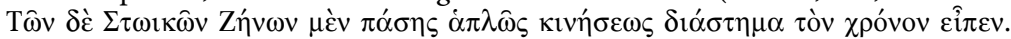

7 Joannes Stobaeus, Anthologium I 8,42 (Ioannis Stobaei Anthologium 1, 106,5-

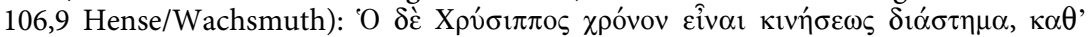

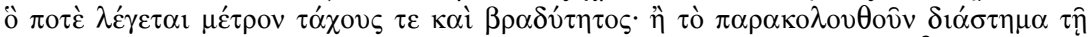

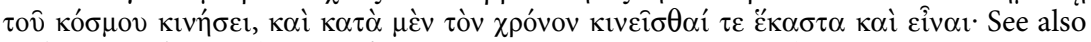
Stobaeus, Eclogae I (SVF II, fragm. 509, 164,15-18 von Arnim).

${ }^{8}$ Rist: Stoic Philosophy (see note 5), 276f.

9 Emile Bréhier: "La Théorie des Incorporels dans l'ancien Stoïcisme," Archiv für Geschichte der Philosophie 22 (1909), (114-125) 119.

${ }_{10}$ Philo, De opificio mundi 26,4 (Philonis Alexandrini opera quae supersunt 1, 8,8

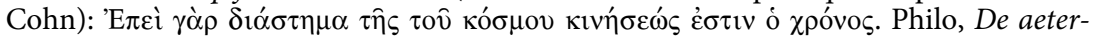
nitate mundi 6,4 (Philonis Alexandrini opera quae supersunt 6, 73,14-74,1 Cohn/ Reiter); 52,5-7 (Philonis Alexandrini opera quae supersunt 6, 89,5-7 Cohn/Reiter):

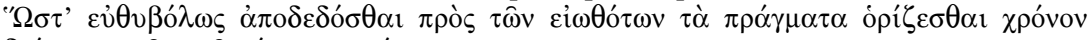

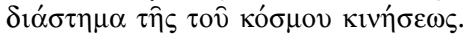


Otis went a step further claiming that Gregory's usage of $\delta$ ió $\sigma \tau \eta \mu \alpha$ resembled that of Methodius of Olympus who adopted this term from Stoic and Philonic sources and adapted it to the Christian perspective on time. ${ }^{11}$ In his early work the Symposium, in his interpretation of the biblical parable on wise and foolish virgins (Mt 25:1-13), Methodius is using the term $\delta i \alpha$ $\sigma \tau \eta \mu \alpha$ to refer to the period before Christ's final coming. ${ }^{12}$ In his later work De resurrectione, Methodius elaborates the notion further, comparing the whale (from the parable of John 1:4-17) with the "time, which never stands still, but is always going on, and consumes the things which are made by longer and shorter intervals". ${ }^{13}$ For Methodius everything exists in time and it is determined by certain $\delta i \alpha ́ \sigma \tau \eta \mu \alpha$. By describing time as a container of all existence Methodius influenced Gregory to coin the term $\chi \omega \dot{\omega} p \eta \alpha \alpha \delta \varepsilon \kappa \tau$ เóv. ${ }^{14}$

In his recent work on Origen, the Greek scholar Tzamalikos considers that Origen also left his mark on Gregory in relation to the concept of $\delta i \alpha ́ \sigma \tau \eta \mu \alpha$ and $\dot{\alpha} \delta i \alpha ́ \sigma \tau \alpha \tau o{ }^{15}{ }^{15}$ Tzamalikos claims that the distinction between $\delta i \alpha ́ \sigma \tau \eta \mu \alpha$, which is creaturely characteristic because "the bodies are created in intervals"16 and $\dot{\alpha} \delta$ ió $\sigma \tau \alpha \tau$ (dimensionless), ${ }^{17}$ which is divine characteristic because God is beyond alteration, change and time, established by Origen is followed by Gregory. Thus is obvious according to Tzamalikos in Gregory's differentiation between

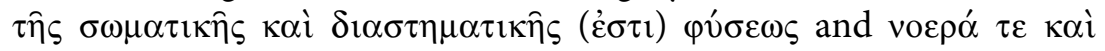

${ }^{11}$ Brooks Otis: "Gregory of Nyssa and the Cappadocian Conception of Time," Studia Patristica 14 (1976), (336-357), 332-336.

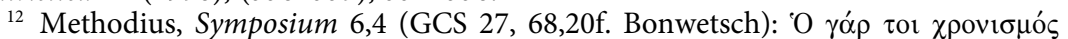

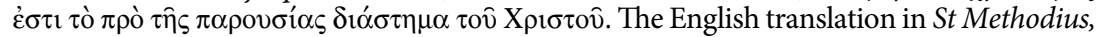
The Symposium: A Treatise on Chastity, translated and annotated by Herbert Musurillo. Ancient Christian Writers 27 (Westminster [Maryland]: Newman, 1958), 94.

${ }_{13}$ Methodius, De resurrectione II 25,2 (GCS 27, 380,19-381,5 Bonwetsch): ”Еoикع

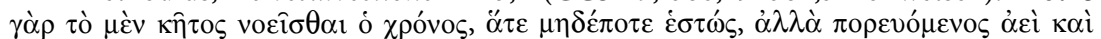

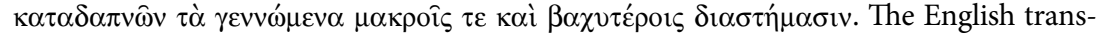
lation is taken from Philip Schaff: Fathers of Third Century: Gregory Thaumaturgus, Dinoysius the Great, Julius Africanus, Anatolius and Minor Writer, Methodiu, Arnobius. The Ante-Nicene Fathers 6 (Edinburgh: T\&T Clark, 1989), 378.

${ }^{14}$ Eun. I 370 (GNO I, 136,10 Jaeger).

15 Panayiotis Tzamalikos: Origen Cosmology and Ontology of Time. Supplements to Vigiliae Christianae 77 (Leiden: Brill, 2006), 223 note 197; 261f. note 365.

${ }_{16}$ Origen, De principiis II 3,2 (GCS 22, 114,21f. Koetschau); English translation from: Origen, On the first principles. Being Koetschau's text of the De principiis, translation into English, together with an introduction and notes by G.W. Butterworth, introduction to the Torchbook ed. by Henri de Lubac (New York: Harper and Row, 1966) 84.

17 Origen, Expositio in Proverbia 2 (PG 17, 168A). 
$\dot{\alpha} \delta t_{\alpha} \sigma \tau \alpha \tau \sigma \varsigma \varphi^{\prime} \sigma \iota^{18}{ }^{18}$ Tzamalikos ${ }^{19}$ also maintains that Gregory is indebted to Origen for the psychological perception of time, i.e. conception that time comprises past, present and future, but it seems to me that a more likely direct source of this idea could be Methodius. ${ }^{20}$

It is worthy to note that one of the likely sources for the cosmological $\delta i \alpha ́ \sigma \tau \eta \mu \alpha$ is Plotinus. Balthasar ${ }^{21}$ and Plass ${ }^{22}$ argue that the Neoplatonists influence Gregory in his teaching on $\delta$ ó $\sigma \tau \eta \mu \alpha$. In Enneades 3,7,6 Plotinus extensively elaborates the definition of time as $\delta 1 \alpha ́ \sigma \tau \eta \mu \alpha$ of movement, together with the definitions of time as number and measure of movement. However, he disagrees that time is $\delta$ ió $\sigma \tau \eta \mu \alpha$ of movement, because $\delta$ ió $\sigma \tau \eta \mu \alpha$ is not something external to movement, but it is placed in movement itself. ${ }^{23}$ Plotinus also uses the term $\dot{\alpha} \delta$ tó $\sigma \tau \alpha \tau o \varsigma$ in describing the eternity as "the life, which belongs to that which exists and is in being, all together and full, completely without extension or interval". ${ }^{24}$

The term $\delta 1 \alpha$ ó $\tau \eta \mu \alpha$ appears with the cosmological meaning specific for Origen and Methodius in the earliest works of Gregory, such as De virginitate, where Gregory states that the life in chastity transcends time, while the marriage and procreation introduce distance between us and the second coming of God by an intervening posterity. ${ }^{25}$

Finally, a highly likely source of Gregory's $\delta i \alpha ́ \sigma \tau \eta \mu \alpha$ is represented by the anti-Arian polemics. The term $\delta i \alpha \sigma \tau \eta \mu \alpha$ is mentioned for the first time in the Trinitarian context by Alexander of Alexandria in the letter to his namesake Alexander the bishop of Thessalonica. Bishop Alexander accuses Arius of introducing time or temporal extension in the divine being by the phrase "it was when the Son was not". ${ }^{26}$

18 An. et res. 48B (BKV I 1, 40,23f. Oehler).

19 Tzamalikos: Origen Cosmology and Ontology (see note 15), 231 note 235.

20 Methodius, De resurrectione II 25,8 (GCS 27, 382,1-6 Bonwetsch); Schaff: Fathers of Third Century (see note 13), 378.

${ }^{21}$ Von Balthasar: Presence and Thought (see note 1), 32f. note 46.

22 Paul Plass: "Transcendent Time and Eternity in Gregory of Nyssa," Vigiliae Christianae 34 (1980), (180-192) 187.

23 Plotinus, Enneades 3,7,7f. (SCBO, Plotini opera 1, 346,1-350,69 Henry/Schwyzer).

24 Plotinus, Enneades 3,7,3 (SCBO, Plotini opera 1, 340,36-38 Henry/Schwyzer):

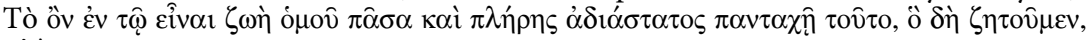
$\alpha i \omega ́ v$.

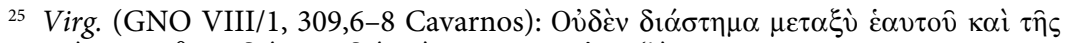

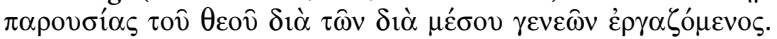

26 Theodoret, Historia ecclesiastica I3,3f. (GCS N.F. 5, 7,24-8,11 Parmentier/Hansen); cf. Theodoret, Jerome, Gennadius, \& Rufinus: Historical Writings, ed. by Philip Schaff. The Nicene and post-Nicene Fathers, 2nd series, vol. 3 (Edinburgh: T\&T Clark, 1994), 37. 
In order to vindicate the divinity of the Son, the Alexandrine bishop rejects any kind of temporal $\delta$ ió $\sigma \tau \eta \mu \alpha$ between the Father and the Son, maintaining that they are coeternal. The term $\delta i \alpha$ ot $\tau \mu \alpha$ was also used by Athanasius the Great, who claims that it is impossible to think of any spatial distance or temporal extension between the Father and the Son, because the Son, being born from the Father, exists in the same way like the Father. ${ }^{27}$

Therefore, by Gregory's time $\delta$ ió $\sigma \tau \eta \mu \alpha$ became a terminus technicus of the anti-Arian and anti-Anomean debates.

\section{Gregory's $\delta i \alpha ́ \sigma \tau \eta \mu \alpha$}

While Gregory synthesizes two distinct meanings of the term $\delta$ tó $\sigma \tau \eta \mu \alpha$, derived from two different milieus, one cosmological and the other Trinitarian, his doctrine of $\delta$ ió $\sigma \tau \eta \mu \alpha$ can hardly be reduced to the existing sources. $\Delta$ có $\sigma \tau \eta \mu \alpha$ has a twofold meaning, which determines the character of every created being. Firstly, $\delta$ ió $\sigma \tau \eta \mu \alpha$ has its temporal component and represents the extension in time. Everything that exists in time is created and it has its place in the temporal order, because the "creation comes into existence according to a sequence of order, and is commensurate with the duration of the ages" ${ }^{28}$ Gregory shows this by the terms $\tau \alpha^{\prime} \xi_{1 \zeta}$ and $\dot{\alpha} \kappa o \lambda o v \theta i \alpha$, broadly analyzed by Daniélou. ${ }^{29}$ Thus, every being has its place in time, ${ }^{30}$ either in relation to the beginning of time, other beings and events in time, or in relation to the end of time and the second coming of Christ. According to Gregory, we are separated from God by time or temporal $\delta ı \alpha ́ \sigma \tau \eta \mu \alpha$. Secondly, Gregory introduces physical or natural $\delta$ ió $\sigma \tau \eta \mu \alpha$ as an ontological gulf between the creator and us. Whatever the degree in deification we gain, $\delta$ ió $\sigma \tau \eta \mu \alpha$ between God and us as well as our

See also Epistula ad Alexandrum Constantinopolitanum = Urkunde 14 22,3 (Athana-

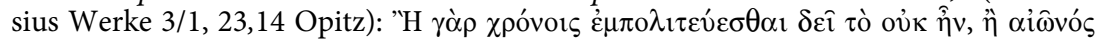

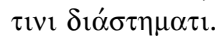

27 Athanasius, De synodis Arimini in Italia et Seleuciae in Isauria 26,9,1f. (Athanasius Werke 2/1, 253,34-39 Opitz).

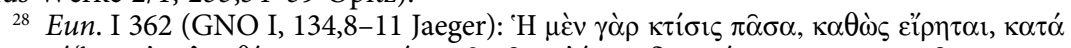

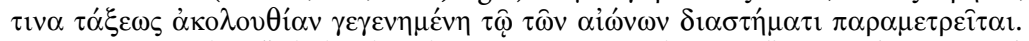

${ }^{29}$ Jean Daniélou: "Akolouthia chez saint Grégoire de Nysse," Revue de science religieuse 27 (1956), 219-249; Jean Daniélou: L'être et le temps chez Grégoire de Nysse (Leiden: Brill, 1970).

${ }^{30}$ Eun. I 369f. (GNO I, 136,1-13 Jaeger). 
deep quest and desire to become one with the divine, remain as the natural mark of creation. Examples of ontological $\delta i \alpha ́ \sigma \tau \eta \mu \alpha$ may be found in Gregory's works such as De vita Moysis, In Ecclesiasten and In canticum canticorum.

In his seminal article on $\delta$ ó $\sigma \tau \eta \mu \alpha$, Verghese lists the possible usages that this Greek word can have in Gregory, from Trinitarian and christological to cosmological and ontological. ${ }^{31}$ Unfortunately, pointing to some apparent contradictions in Gregory's usage of this term seems that Verghese does feel the subtlety of Gregory's teaching of $\delta i^{\prime} \sigma \tau \eta \mu \alpha$. The Verghese problem how to reconcile the paragraph from In canticum canticorum ${ }^{32}$ where Gregory claims that at the beginning of creation the $\dot{\alpha} \rho \chi \eta \dot{~ o f ~ c r e a t e d ~ b e i n g s ~ w a s ~ c o-p e r f e c t e d ~}$ with the $\pi \dot{\varepsilon} \rho \alpha \varsigma$ without $\delta i^{\prime} \sigma \tau \eta \mu \alpha$ with his position that $\delta$ ió $\sigma \tau \eta \mu \alpha$ is an inseparable characteristic of created beings, could be solved by reading this paragraph against the passages from De perfectione ${ }^{33}$ and De vita Moysis. ${ }^{34}$ Gregory's teaching about perfection not as a state but as a constant effort to attain the attainable is a key to distinguish between ontological $\delta i \alpha \sigma \sigma \tau \eta \mu \alpha$ and the $\delta i \alpha \dot{\sigma} \sigma \eta \mu \alpha$ caused by the fall.

It should be also mentioned the original reading of Gregory's $\delta i \alpha ́ \sigma \tau \eta \mu \alpha$ offered by Scot Douglass. Scot Douglass claims that the lack of $\delta i \alpha$ $\sigma \tau \eta \mu \alpha$ between the persons in the Trinity causes the lack of the communication among them, ${ }^{35}$ because according to Gregory what is totally conjoined is not mediated by speech..$^{36}$ Douglass has also given significant contributions to Gregory's teaching on divine energies that bridge the "diastemic" gap between God and creation. ${ }^{37}$

\footnotetext{
${ }_{31}$ Paul Verghese: " $\Delta$ ió $\sigma \tau \eta \mu \alpha$ and $\delta 1 \alpha ́ \sigma \tau \alpha \sigma ı \varsigma$ in Gregory of Nyssa," in: Gregor von Nyssa und die Philosophie: Zweites internationales Kolloquium über Gergor von Nyssa, Freckenhorst bei Münster. 18.-23. September 1972, ed. by Heinrich Dörrie, Margarete Altenburger and Uta Schramm (Leiden: Brill, 1976), 243-260.

${ }^{32}$ Cant. XV 6,8 (GNO VI, 457,21-458,3 Langerbeck).

${ }^{33}$ Perf. (GNO VIII/1, 214,4-6 Jaeger).

34 Vit. Moys. II (GNO VII/1, 115,8-119,6 Musurillo).

${ }_{35}$ Scot Douglass: Theology of the Gap: Cappadocian Language Theory and the Trinitarian Controversy. American University Studies 7/235 (New York: Peter Lang, 2005), 64.

${ }^{36}$ Eun. II 214 (GNO I, 287,22-288,3 Jaeger).

37 Douglass: Theology of the Gap (see note 35), 9.
} 


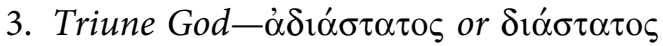

The notion of $\delta i \alpha \sigma \tau \tau \mu \alpha$ as an ontological characteristic of man helps Gregory to coin the opposite notion $\alpha \gamma \varepsilon$ vv $\eta \tau$ s , which he attributes to God. As $\delta i \alpha ́ \sigma \tau \eta \mu \alpha$ has a twofold nature, one as temporal extension and the other as ontological gulf between the creator and creation, the

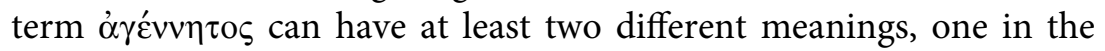
temporal, and another in the ontological realm. The lack of temporal $\delta$ ió $\sigma \tau \eta \mu \alpha$ in the divine Being implies that God cannot be in any sense subsumed under the category of time and any other category in which exists change in relation to the subsequent state. This is evident in the attitude of the Cappadocians who do not allow any temporal extension between the Father and the generation of the Son. ${ }^{38}$

However, the Anomean party claims that their own teaching also admits the lack of temporal extension in God, accusing their opponents, probably the orthodox party, that they are those who introduce time in God, even calling them "temporists" ( $\chi \rho \operatorname{povi} \tau \alpha){ }^{39}$ Aetius and his disciple Eunomius maintain that by the claim that the eternal Father begets the eternal Son their opponents introduce time in God. According to the Anomean teaching, every generation must be in time because it implies some temporal extension between the begetter and the begotten.

In 1968 Wickham listed three main Anomean arguments, which deal with introducing time in the divine being. Firstly, the claim of the orthodox party that $\alpha_{\gamma} \varepsilon^{\prime} v v \eta \tau o \varsigma$ and $\gamma^{\prime}{ }^{\prime} v \eta \eta \mu \alpha$ share the same essence means, according to the Anomeans, that divine essence is divided by generation. ${ }^{40}$ Moreover, the Anomeans state that the generation implies change and the change introduces time to the divine being. ${ }^{41}$ Secondly, the Anomeans accuse their opponents that, by the teaching that the Son is of one substance with the Father, but that he is second in order after the Father, they introduce time in the divine being, because the

${ }^{38}$ Eun. I 362 (GNO I, 134,8-11 Jaeger); Basil of Caesarea, Adversus Eunomium II 13 (SC 305, 46,1-50,38 Sesboüé).

${ }_{39}$ Epiphanius, Panarion 76,11,3 (GCS 372 352,15 Holl/Dummer). The English translation of Aetius' Syntagmation in Lionel R. Wickham: "The Syntagmation of Aetius the Anomoean," The Journal of Theological Studies 19 (1968), (540-549) 540.544. See also Eunomius, Apologia 10,1-17; 22,1-15 (OECT, 44.62 Vaggione).

${ }^{40}$ Lionel R. Wickham: "The Syntagmation of Aetius the Anomoean," Journal of Theological Studies 19 (1968), (532-569) 550.

${ }^{41}$ Epiphanius, Panarion 12,8 (GCS 372 $353,22-354,4$ Holl/Dummer). 
Son can be only second in time after the Father. ${ }^{42}$ The third Anomean

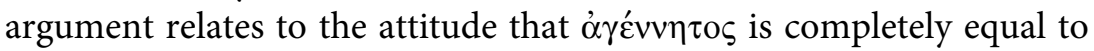
$\gamma \varepsilon ́ v v \eta \mu \alpha$ ("save generation"). By this claim the orthodox party, accord-

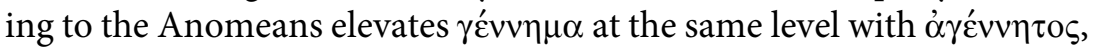
which implies change and consequently time..$^{43}$ Gregory's reasoning is similar regarding the matter that every extension introduced between the Father and the generation of the Son is subsumed under the objective criterion of measurement, which can only be in time. This leads to the conclusion that every $\delta$ ió $\sigma \tau \eta \mu \alpha$ or extension in the created world necessarily implies the existence of change and consequently time. ${ }^{44}$ On the contrary, the lack of temporal extension and the change from one state to another should imply the eternal existence. However, Gregory changes the perspective by looking at eternity as objective category. While time is the medium in which history happens, eternity is not the medium in which divine being exists. The divine eternity is the attribute of God and for this reason Gregory applies the adjective óílos only to God. ${ }^{45}$ Therefore, eternity is one among other divine attributes such as incomprehensibility, infinity, perfection, goodness and it is one of the divine uncreated energies and in no way the objective container of divine life.

If the lack of temporal $\delta$ ió $\sigma \tau \eta \mu \alpha$ in God leads us to divine eternity, what would involve then the lack of ontological $\delta$ ió $\sigma \tau \mu \alpha$ ? The ontological $\delta i \alpha ́ \sigma \tau \eta \mu \alpha$ as a gulf between created and uncreated nature ensures the constant desire from the side of created nature to find stability in uncreated nature and the consequent movement toward divine being. Therefore, the adjective $\alpha \delta$ ió $\sigma \tau \alpha \tau o \zeta$ denies not only the existence of $\delta$ ió $\sigma \tau \eta \mu \alpha$ as a temporal category, but also the lack of any desire, which refers to the deprivation ( $\sigma \tau \varepsilon \dot{\varepsilon} \eta \sigma ı \varsigma)$ of a certain quality in the divine being. The divine being is perfect by itself and its perfection is not the consequence of participation in something perfect or the result of constant movement toward a goal, which gives the basis for

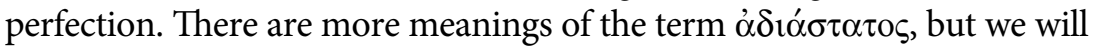
focus on the context in which this term appears in Ad Ablabium.

${ }^{42}$ Eunomius, Apologia 10,4-12 (OECT, 44 Vaggione).

${ }^{43}$ Epiphanius, Panarion 76,12,8 (GCS 372, 353,22-354,4 Holl/Dummer).

${ }^{44}$ Eun. I 363 (GNO I, 134,13-17 Jaeger).

${ }^{45}$ Eun. I 371 (GNO I, 136,14-22 Jaeger). 


\section{Gregory's Ad Ablabium}

The term $\dot{\alpha} \delta$ ió $\sigma \tau \alpha \tau$ os appears only once in the work dedicated to Ablabius, but inspires Gregory's argumentation more than any other of the divine attributes. Almost all arguments from Ad Ablabium echo the debate with the Anomean party. Moreover, all these arguments could be seen as replies to the accusation of the Anomeans that the orthodox party introduces time or temporal $\delta i \alpha ́ \sigma \tau \eta \mu \alpha$ in God. The scholarly consensus has been formed over the attitude that cosmological interest shaped the thought of both sides (Rowan Williams, ${ }^{46}$ Maurice Wiles). ${ }^{47}$ I would like to go further and to demonstrate that both, the Anomeans and the Orthodox, agreed regarding the point that there is no temporal $\delta \dot{\alpha}^{\sigma} \sigma \tau \eta \mu \alpha$ in God. Therefore, I will analyze Gregory's arguments in Ad Ablabium as the refutation of the Anomean accusation of the orthodox party of introducing time in God. Moreover, I attempt to demonstrate that Gregory's arguments follow and reject the Anomean arguments listed by Wickham, one by one.

The first argument of the Anomeans noted by Wickham accuses the orthodox party of dividing the common essence by claiming that the ingenerate and the only begotten share a common essence, and as a result of this change time or temporal $\delta$ ió $\sigma \tau \eta \mu \alpha$ in God appears.

After warning against speaking of God in plural in order to avoid any resemblance to the polytheism of pagans, Gregory launches the first theological argument, which meets the Anomean accusation. He argues that while the idea of persons admits separation, the idea of nature is inseparable and the divine "nature is one, at union in itself and an absolutely indivisible unit". ${ }^{48}$ For Gregory the essence is always one, "inseparable even though it appear(s) in plurality, continuous, complete, and not divided with the individuals who participate in it". ${ }^{9}$

\footnotetext{
${ }^{46}$ Rowan Williams: Arius: Heresy and Tradition (Grand Rapids: Eerdmans, 2002), 181-214.

${ }^{47}$ Maurice Wiles: "The Philosophy of Christianity. Arius and Athanasius," in: The Philosophy in Christianity, ed. by Godfrey Vesey. Royal Institute of Philosophy supplement 25 (Cambridge: Cambridge University Press, 1989), 41-52.

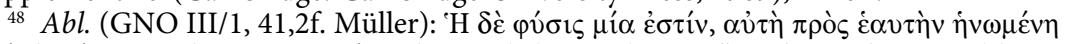

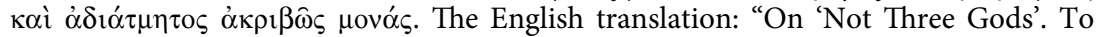
Ablabius," in: Gregory of Nyssa: Dogmatic Treatises, select writings and letters, ed. by Philip Schaff. The Nicene and post-Nicene Fathers 5 (Grand Rapids: Eerdmans, 1892), (331-336) 332.

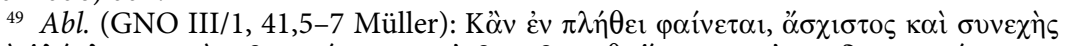

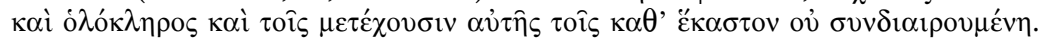


Claiming that the divine essence is not divided by the participation of the ingenerate and only begotten, Gregory rejects the possibility that any change is introduced in the common essence. The common essence or nature of God is not "capable of increase by addition or of diminution by substraction". ${ }^{50}$ Therefore, one cannot speak of any change and appearance of time or temporal $\delta i \alpha ́ \sigma \tau \eta \mu \alpha$ in the divine being. It is easy to conclude after Gregory's arguing that there is no $\delta ı \alpha ́ \sigma \tau \eta \mu \alpha$ in divine essence and that God is $\dot{\alpha} \delta 1 \alpha \sigma \tau \alpha \dot{\tau} \tau o \zeta$.

The second Anomean argument for introducing time to God is based on the claim that while the essence is common to all divine persons, they differentiate by order. For Eunomius the order, which presupposes superiority or inferiority, has to be in time..$^{51}$ Therefore, according to Anomeans there must be temporal extension between the unbegotten and the only begotten if there is precedence. What kind of precedence has the orthodox party in mind if not precedence in time? Gregory is quite clear when he claims that there is no divisibility and separability in divine nature ${ }^{52}$ or essence that can imply precedence in order. While Gregory denies any order in common substance, he affirms the specific order in divine operation. Thus, he claims that "every operation which extends from the God to the Creation, [...] has its origin from the Father, and proceeds through the Son, and it is perfected in Holy Spirit". ${ }^{53}$

It is obvious that there is a certain order in divine operation, because the Father is the origin of it and the first in order, the Son is second in order and the intermediary between the Father and the Holy Spirit, while the Holy Spirit is the third and the last in order and every operation is perfected in him. However, Gregory does not stop here, but aware of the possible Anomean charge proceeds further, denying that divine operation is a separate action according to the number of the persons, and describing it as "one motion and disposition of the good

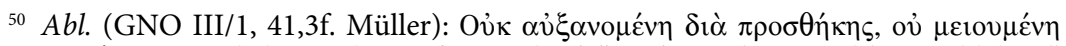
$\delta$ ' í $\varphi \propto \imath \varepsilon \varepsilon ́ \varepsilon \varepsilon \omega s$. English translation from Schaff: "On 'Not Three Gods'. To Ablabius" (see note 48 ), 332.

${ }^{51}$ See Eunomius, The Extant Works, text and translation by Richard P. Vaggione. Oxford Early Christian Texts (Oxford: Clarendon Press, 1987), 45.

${ }_{52} \mathrm{Abl}$. (GNO III/1, 46,15f. Müller). English translation from Schaff: "On 'Not Three Gods'. To Ablabius" (see note 48), 333.

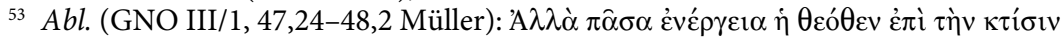

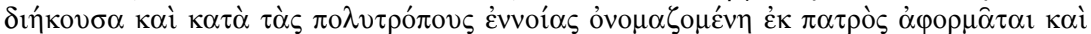

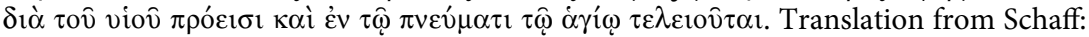
"On 'Not Three Gods'. To Ablabius" (see note 48), 334.
} 
will" ${ }^{54}$ All good things and all good names are the result of this motion of good. Gregory finally rejects Eunomius' stance that superiority or precedence is based in time, by claiming that God's operation is "without mark of time or distinction since there is no delay, existent or conceived, in the motion of the Divine will from the Father, through the Son to the Spirit". ${ }^{55}$

Here, Gregory for the first and last time in Ad Ablabium uses the term $\dot{\alpha} \delta 1 \alpha \sigma \tau \alpha \tau o \varsigma$ and he pairs it with the term óxpovos, showing that the order in divine operation has nothing to do with temporal or other kind of extension. By using the term o'xpovos, Gregory rejects any possibility that time or temporal extension divides the process of operation between the Father and the Son or the Son and the Holy Spirit. The process of divine operation is based on "the unity of actions, which prevents plural enumeration" ${ }^{56}$ The second adjective $\dot{\alpha} \delta i \alpha ́ \sigma \tau \alpha \tau o \varsigma$ denies not only the existence of the temporal $\delta$ ió $\sigma \tau \eta \mu \alpha$ in divine essence and energies, but also abolishes any kind of distinction between the three divine persons.

The next and the last Anomean accusation is that the Orthodox attempt to elevate the second to the status of the first and thus make Father and Son equal. Therefore, Aetius claims that "making generate to become ingenerate" ${ }^{17}$ introduces change again and consequently time.

However, this is not the only problem which Gregory faced. By

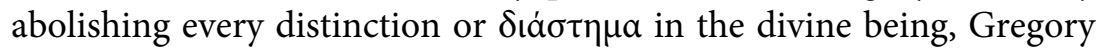
finds himself in the difficulty how to distinguish three divine persons one from the other. The same problem seen from the Anomean perspective would be how to distinguish three equally divine persons, and not to disturb their divinity either on the level of ovoí $\alpha$ or on

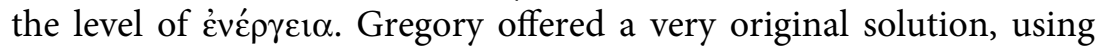
the same rationale as the Anomeans. While the Anomeans used the distinction between ingenerated and generated to claim the difference

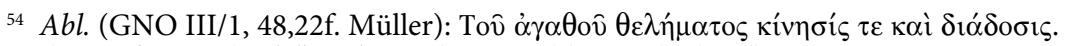
Translation from Schaff: "On 'Not Three Gods'. To Ablabius" (see note 48), 334.

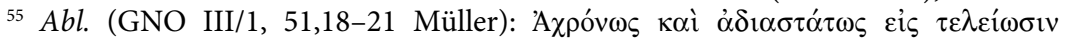

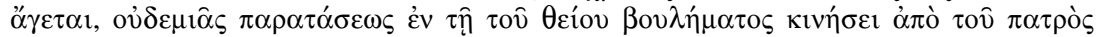

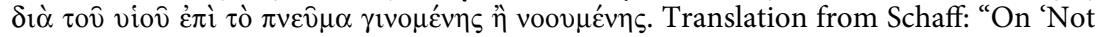
Three Gods'. To Ablabius" (see note 48), 335.

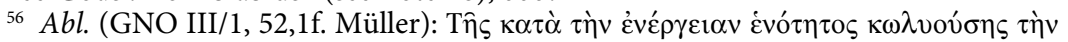

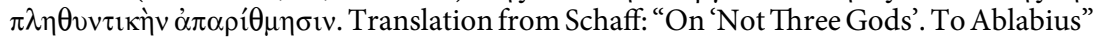
(see note 48), 335.

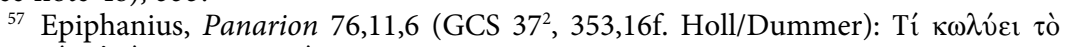

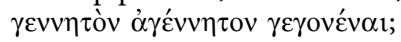


in substance between the two, Gregory, preserving the unity of divine substance and operation, used the same distinction to show the difference between persons. Michel René Barnes correctly pointed out that, while Athanasius and his contemporaries used the doctrine of divine generation to prove that the Father and the Son have the same nature or essence, for Gregory the same doctrine served as a basis for distinguishing persons..$^{58}$ It is easy to agree with Barnes that Gregory's move represents the major development in Trinitarian theology from the time of early Arian controversy.

However, the language "ingenerate-generated" needed some adaptation in order to be applicable to the new Trinitarian context, which respects the full divinity of the Holy Spirit. Therefore, Gregory introduced a new language of causality by securing the invariable character of nature denying any distinction in it. ${ }^{59}$ Gregory makes the differentiation between the persons on the basis of causality. Thus, Gregory introduces double differentiation. The first differentiation is in relation to the cause and to that which is caused. It is possible here to detect the influence of Gregory's older brother Basil, especially at the level of language and reasoning. Firstly, the term "the invariable character of

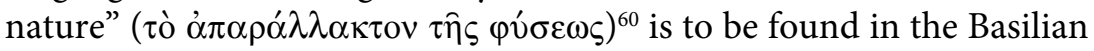
vocabulary and it is a substitute for ómoov́riov. ${ }^{61}$ Secondly, the identification of the Father with the cause and source ( $\left.\alpha i \tau^{i} \alpha\right)$ is also made by Basil in order to establish the unity of God on the $\mu$ ov $\alpha \rho \chi^{i} \alpha$ of the Father. ${ }^{62}$ However, it does not seem that Gregory follows his brother on this point. The language "cause-caused" circumscribes a larger class of objects, than the language "ingenerated-generated" and thus Gregory subsumes under the term caused both the Son and the Holy Spirit and gives a broader Trinitarian perspective. On this point Gregory makes a new departure from the previous Nicene theology. He preserves the characteristic of the Father to be uncaused, but he transfers this attribute from the level of nature to the level of person. As Barnes noticed, the unqualified use of "uncaused" no longer functions as the criterion for divinity ${ }^{63}$ The term "uncaused" applied

\footnotetext{
${ }^{58}$ Michel R. Barnes: “Divine Unity and the Divided Self," Modern Theology 18 (2002), (475-496) 483.

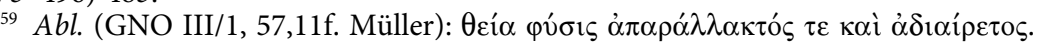

${ }^{60} \mathrm{Abl}$. (GNO III/1, 55,24 Müller).

${ }^{61}$ Basil of Caesarea, Homilia contra Sabellianos, et Arium, et Anomoeos 4 (PG 31, 608A).

${ }^{62}$ Basil of Caesarea, Epistula 38,4 (CUFr, Lettres 1, 84,1-87,93 Courtonne).

${ }^{63}$ Barnes: "Divine Unity and the Divided Self" (see note 58), 484.
} 
to the Father does not refer just to his relationship with the Son, but also to the relationship with the Holy Spirit. While the language "ingenerate-generate", describes the Father's relationship to the Son, the language "uncaused-caused" enables to understand the personal distinction of the Father in relation to both the Son and the Holy Spirit. However, the term caused serves as an intermediary term because it is applicable to the class of two objects, namely the Son and the Holy Spirit, and it does not fully describe their personal characteristics of the caused persons. Therefore, Gregory proceeds further distinguishing the Son from the Holy Spirit on the basis of their relations to the Father and also on the basis of the relations between the two of them. Thus, for Gregory the Son is directly from the first cause, and the Holy Spirit is by that which is directly from the first cause, namely by the Son. ${ }^{64}$ Gregory's claim taken out of the context of the argument can lead to the conclusion that there is subordination in the Holy Trinity. However, Gregory insists on something else here. His intention is to describe the personal characteristic of the Son by the attribute only begotten, which preserves the relationship with both the Father and the Holy Spirit. By being begotten, the Son relates to the Father who is unbegotten and the begetter of the Son. By the prefix "only" added to begotten, the Son also relates to the Holy Spirit, telling us that the Holy Sprit is caused but not begotten. Thus, the Son is the only one who is begotten by the cause and therefore is only begotten, while the Holy Spirit is also from the Father, but he is not begotten. Here Gregory emphasizes that the terms "cause" and "from the cause" have nothing to do with the divine nature, and like the terms "generate" or "ingenerate" refer to the personal attributes of the divine persons. The distinction that Gregory makes between the nature and the persons of the Holy Trinity is based on the differentiation between the existence and the mode of existence or as Gregory puts it between $\tau$ ' $\dot{\varepsilon} \sigma \tau \imath$ and $\pi \hat{\omega} \varsigma \dot{\varepsilon} \sigma \tau \imath^{65}$ At the end of the work, Gregory concludes: "we can no longer be accused of confounding the definition of the Persons by the community of nature". ${ }^{66}$ The word "we" obviously refers to Gregory, his brother Basil and the entire orthodox party, but the question from

${ }^{64} \mathrm{Abl}$. (GNO III/1, 56,5-10 Müller). Translation from Schaff: "On 'Not Three Gods'. To Ablabius" (see note 48), 336.

${ }^{65} \mathrm{Abl}$. (GNO III/1, 56,11-22 Müller).

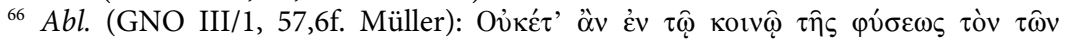

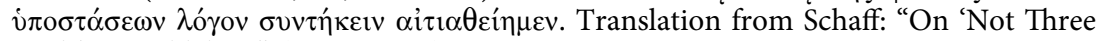
Gods'. To Ablabius" (see note 48), 336. 
which side the accusations originate still remains. It seems to me that the charge for confusing the definition of the Persons with the community of natures comes from the Anomeans, because it hides neoArian logic. Therefore, the last of Gregory's arguments can be seen as a reply to the Anomean charge that the elevation of the second to the status of the first or better said making the second equal with the first within the common essence introduces the change and time to God.

Gregory replies to the Anomean charge with the same claim that

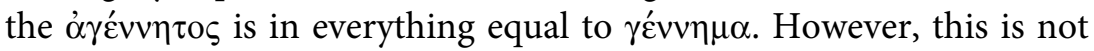
an elevation in the divine essence and energies because there is no temporal or spatial $\delta i \alpha \sigma \tau \eta \mu \alpha$ between the persons in divine essence that can be passed on the course of elevation. The distinction between the divine persons does not have a temporal character, it is rather differentiation concerning their personal properties.

Thus, through the course of his argumentation, Gregory refutes all Anomean charges listed by Wickham, which accuse the Orthodox party of introducing change and temporal $\delta \iota^{\alpha} \sigma \tau \eta \mu \alpha$ to God. Gregory shows that God is and always remains $\dot{\alpha} \delta 1 \alpha \sigma \tau \alpha \dot{\tau} \tau o \varsigma$.

\section{Conclusion}

It is evident that the work Ad Ablabium is written in a polemical tone. Gregory argues not only against the charges that Christians confess three Gods, but also against some Anomean accusations, which imply temporal distinction in the divine being. Therefore, Gregory's development of the doctrine of the "adiastemic" nature of God, shows that there is no separation or $\delta i \alpha ́ \sigma \tau \eta \mu \alpha$ in the divine essence and operations. Gregory applied the argumentation developed on the course of refuting Eunomius to the Trinitarian context of the work Ad Ablabium. I have tried to demonstrate that by focusing on the Anomean accusations that the Orthodox introduces time in divine being, Gregory not only rejects these charges, but also develops a new Trinitarian doctrine. Thus, the newly developed theory presupposes two things, the "adiastemic" unity of the divine essence and energies, together with the "hypostatic" distinction between the persons. 